\title{
Elizabethan Diplomatic Networks and the Spread of News
}

\author{
Tracey A. Sowerby
}

Sir Thomas Smith, Elizabeth I's ambassador in France, wrote to her longest serving secretary, Sir William Cecil, in 1563 that "yf ye did understand and feele the peyne that Ambassadoures be in when thei can have no aunswer to ther lettres nor intilligence from ther prince, nor hir cownsell, ye wold pitie them I assure yow". This pain was particularly acute, Smith went on to explain, when there were worrying rumours, such as those circulating at the French court that Queen Elizabeth was dead or very ill. ${ }^{1}$ Smith was far from the only Elizabethan ambassador to highlight the importance of regular news from home. Almost every resident ambassador Elizabeth sent abroad did so at some point during his mission. Practical and financial considerations meant that English ambassadors often had to wait longer than was desirable for domestic news; it was not unusual for ambassadors to go for one or two months without any news from the Queen or her Privy Council. For logistical reasons diplomats posted at courts relatively close to London were more likely to receive more regular information from court than those in more distant courts such as those of the Spanish king or Ottoman Emperor, or who were attached to semi-peripatetic courts. There were financial reasons too: sending a special post from Paris to London and back cost at least $£ 20$ in $1566 .{ }^{2}$ But sending news through established postal routes or with other ambassadors' packets, while considerably cheaper, was also much less secure and took longer. ${ }^{3}$

A lack of news could hinder a diplomat's ability to operate effectively. A letter or news from his own Queen was an excuse to ask for an audience; without either an ambassador might not be able to argue for access to his host monarch and would consequently lose opportunities to assess foreign politicians before

1 TNA, SP 70/64, fo. 4or [J. Stevenson, A.J. Butler and S.C. Lomas, eds., Calendar of State Papers, Foreign Series, of the Reign of Elizabeth (London, 1863-1950; 23 vols. in 26) (hereafter CsPF), 6: 1292]. All references to Calendars are to document, not page numbers.

2 British Library, Additional Ms 18764, fo. 1 .

3 On the European postal system in the sixteenth century see E. John B. Allen, Post and Courier Service in the Diplomacy of Early Modern Europe (The Hague: Martinus Nijhoff, 1972); see also Ch. 2, above.

(C) TRACEY A. SOWERBY, 2016 | DOI 10.1163/9789004277199_014

This is an open access chapter distributed under the terms of the Creative Commons Attribution-

Noncommercial-NoDerivatives 3.o Unported (CC-BY-NC-ND 3.0) License. 
controversial issues arose. ${ }^{4}$ As Sir Thomas Chaloner commented, it was an "advancement to thambassadors reputacion when he hearith often from home, not to sem ignorant in charges that others of the cort shall talke and discource apon". ${ }^{5}$ He claimed that not being able to discuss recent English affairs authoritatively with foreign courtiers "gevith cawse of despayre" and insisted that "whither it be ought or naught, it is no reason I shuld here thereof at other folkes, and be axed the question of that, that I thincke" and be unable to answer. Not knowing the latest English news, Chaloner opined, undermined his status and raised questions about how much Elizabeth valued her ambassador: he wrote that foreign courtiers believed, as he did, that "I owght partely to understand" domestic news "by expresse letters unlesse I be sent hither rather as an hostage then for an Ambassador". ${ }^{6}$ Moreover, when an ambassador did receive news, it needed to be current in order to be useful. Chaloner, like other Elizabethan diplomats, was often disappointed with the frequency and quality of information he received from home, complaining that it sometimes arrived in Spain "no lesse stale, then out of Season".7 The need for intelligence from home was particularly acute at moments of political crisis, when any uncertainty over England's position might encourage interference from overseas powers or suggest that Elizabeth did not trust her proxy. Moreover, as the possession of current information was a sign of political connections and even alliances, an ambassador's lack of news might signal that his master was politically isolated.

News was essential to the conduct of early modern diplomacy. Yet the role that diplomatic actors and networks played in the spread of news has received surprisingly little scholarly attention. This essay will first use the experiences of Sir Thomas Chaloner, who served as Elizabeth's ambassador in the Netherlands and Spain during the early years of her reign, to explore the nature and extent of diplomatic information networks, before turning to the role that Chaloner and other Elizabethan ambassadors played in the transnational dissemination of newsletters and news pamphlets.

The personal and professional networks that a diplomat maintained were essential to his access to news and to the role that he played in dispersing it. Chaloner's networks while ambassador to the court of Philip II between November 1561 and May 1565 are an instructive case study. An ambassador

4 CSPF, 5:435.

5 TNA, SP 70/8, fo. $131 \mathrm{~V}[C S P F, 2: 240]$.

6 TNA, SP 70/40, fo. 259 [ [CPSF, 5: 557].

7 Samuel Haynes, ed., A Collection of State Papers, Relating to Affairs in the Reigns of King Henry VIII, King Edward VI, Queen Mary and Queen Elizabeth (London, 1740), p. 383. 
could expect to receive news of domestic and international affairs from the Queen and her Council. Chaloner's main sources of official information while on embassy were the letters he received from Cecil, the Queen or the Privy Council. These served both as letters of instruction and as overviews of important domestic and international developments. ${ }^{8}$ Crucially, they were supplemented by letters and news from individual councillors, particularly John Mason, a "frende whom neither troble of writing ne other busyness stayeth from consideraunce of pore mens cases abrode", who wrote to him on a fairly regular basis. ${ }^{9}$

Chaloner relied on Elizabeth's ambassador in France for English and foreign news throughout his mission. Letters from the Privy Council and news from England were sometimes sent via Nicholas Throckmorton, Elizabeth's first resident ambassador in France, giving Throckmorton an opportunity to add his own missives. ${ }^{10}$ Most importantly, Throckmorton updated Chaloner on French politics and the volatile religious situation in France. ${ }^{11}$ Certainly Chaloner felt that he was sufficiently acquainted with French affairs to write an epic poem about the religious struggles in France. ${ }^{12}$ As he received regular news from Thomas Randolph, Elizabeth's ambassador in Scotland, Throckmorton was often able to inform Chaloner of developments there too. ${ }^{13}$ On several occasions he included information about mercantile matters that Chaloner might encounter. ${ }^{14}$ Moreover, when Chaloner was travelling to Spain, he stopped at the French court, which gave him the opportunity to debrief with Throckmorton in person..$^{15}$ This was not a one-way flow of information. Chaloner in turn informed Throckmorton of developments in Spain. ${ }^{16}$ Just as Chaloner received several packets of letters that had been routed via Throckmorton at the French court, he sent letters to the Queen and

\footnotetext{
$8 \quad \operatorname{CSPF}, 7: 304,461$.

9 TNA, SP 70/40, fo. 259r [CPSF, 5: 557]; BL Cotton MS Vespasian VII, fos. 220r-1r; $C S P F, 5$ : 277,$827 ; 6: 420,1027,1098,1122 ; 7: 220,265$.

$10 \quad \operatorname{CSPF}, 4: 804,847$.

11 BL Cotton MS Caligula EV, fos. 164r-5r; BL Add Ms 35830, fos. 226r-7r; csPF, 4: 735, 804, 847, 1076; 5: 188, 333, 413, 1466; Hatfield House, Cecil Papers, 153/102.

$12 \quad \operatorname{CSPF}, 5: 1309 ; 6: 545,547$.

$13 C S P F, 4: 455$, 986; Joseph Bain, William K. Boyd, Annie Dunlop, and M.S. Giuseppe, eds., Calendar of State Papers Relating to Scotland and Mary, Queen of Scots, 1547-1603, 13 vols. in 14 (1898-1969), 2: 15, 23 .

$14 \quad \operatorname{CSPF}, 4: 847$.

$15 \quad \operatorname{csPF}, 4: 684,682,804,961,988$.

$16 \quad \operatorname{CSPF}, 4: 678,708 ; 804,847,1028 ; 5: 58,88,138,139,171,215,248,266,527,5^{28}, 1466 ; 6: 415 ; \mathrm{BL}$ Additional Ms 35831, fos. 24r-26r; Hatfield House, Cecil Papers, 153/99, 201/141.
} 
the Council via Throckmorton. ${ }^{17}$ At other times Chaloner sent Throckmorton duplicate copies of his letters, which he expected to be forwarded to Cecil or the Queen, sending another copy by a different postal route, often that through Flanders, giving Throckmorton an opportunity to read the letters before he passed them on. ${ }^{18}$ In these instances, sending two copies by different routes served the dual purpose of providing an update to the ambassador at the French court and giving the letters a better chance of arriving at their intended final destination. This correspondence between diplomats ensured that Elizabeth's ambassadors in Spain and France were kept relatively well informed of developments in the other country that might impact on the political situation in that to which they were posted.

All of Chaloner's official sources of news were, however, interrupted by the religious wars in France at one point or another, meaning that some letters took months longer than usual to arrive. ${ }^{19}$ As a result, Chaloner frequently complained of a lack of news. When a letter from arrived Peter Osborne, a prominent administrator and old associate of Chaloner's, in March 1562, Chaloner claimed that it was the first letter he had received from England since his arrival at the Spanish court in January from someone other than his servants or family. ${ }^{20}$ On another occasion he complained that he had not heard any official news from Elizabeth's court for over five months. ${ }^{21} \mathrm{He}$ hoped that letters from friends at court might compensate but even Osborne, who was an experienced administrator with court connections, was not viewed by Chaloner as a courtly source of information. ${ }^{22}$ The lack of news no doubt contrasted with the more frequent updates Chaloner had received on his previous mission to the Netherlands. Another reason he felt the inadequacy so keenly was Philip II's increasingly expansive news network. ${ }^{23}$ This had caused Chaloner some anxiety during his earlier mission to the Netherlands, as Philip's ambassador in England had sent weekly reports to Philip's regent, in contrast to Chaloner's less frequent communications from the English Privy Council. ${ }^{24}$

\footnotetext{
$17 \quad \operatorname{CSPF}, 4: 1028 ; 5: 172,436$.

$18 \quad C S P F, 4: 1028 ; 5: 139,172,188,248,333$.

19 On problems with the post see $c S P F, 5: 46,58,336,433$.

$20 \quad \operatorname{CSPF}, 4: 961$.

$21 \quad C S P F, 5: 482$. See also $C S P F, 4: 961,1018,1028 ; 5: 46,234,435,859$.

$22 \quad C S P F, 4: 1028$.

23 On Philip's news network see Cristina Borreguero Beltrànin, 'Philip of Spain: The Spider's Web of News and Information', in The Dissemination of News and the Emergence of Contemporaneity in Early Modern Europe, ed. Brendan Dooley (Farnham: Ashgate, 2010), pp. $23-50$.

$24 \quad C S P F, 2: 240$.
} 
Moreover, Chaloner was acutely aware that some members of Philip's council received regular newsletters from across Europe and that he did not have the resources to compete. ${ }^{25}$ During Chaloner's embassy in Spain, the situation was worse still. He even commented that he would be like Edmund Bonner, one of Henry vin's diplomats, who Chaloner claimed had been forced to rely on the Holy Roman Emperor's minister for news from England. ${ }^{26}$

Chaloner's network of official contacts was supplemented by professional and personal networks. Chaloner communicated with his predecessor in Spain, Thomas Chamberlain, giving him a further source of French and then English news as Chamberlain slowly made his way back to the English court. ${ }^{27}$ Family, servants, and friends from outside the council and court were useful sources of information, albeit he does not appear to have been in regular contact with many them. His younger brothers John and Francis wrote occasionally, as did his sister Ellen. ${ }^{28}$ His servant Robert Farnham acted as Chaloner's agent in England, sometimes providing information about domestic developments too. ${ }^{29}$ William Honnyng, one of the clerks of the signet, was a source of court news and Peter Osborne similarly provided useful information about English politics. ${ }^{30}$ Chaloner also corresponded with his old friend Henry Killigrew, Nicholas Throckmorton's former secretary and one of Robert Dudley's clients, who was a useful, if infrequent, source of court gossip and rumours about Scottish politics. ${ }^{31}$ Meanwhile, another contact sent Chaloner news of the Queen's progress in $1564 .{ }^{32}$ Chaloner received letters from such correspondents on an infrequent basis, meaning that they too did not provide him with reliable access to the latest news from home.

Chaloner also relied upon the mercantile community to provide him with information about political, religious and economic developments at home, in Spanish territories, and in the wider world. In some cases, his initial correspondence with merchants was about practicalities such as dealing with the

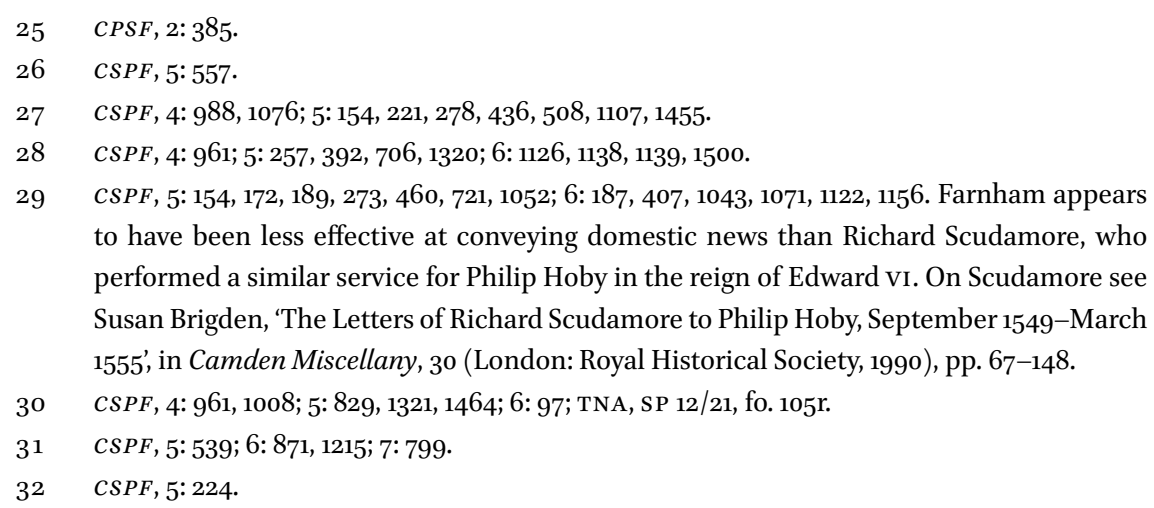


Spanish Inquisition or how to acquire imported food. ${ }^{33}$ Such relationships based on brokerage could turn into more substantive sources of information, as was the case with Chaloner's relationship with John Cuerton, an English merchant based in Spain, who soon became a regular correspondent. In his letters, Cuerton relayed news about England, France, the Netherlands and Spain that he had heard from his mercantile contacts. ${ }^{34}$ As he had previously been posted in the Netherlands, Chaloner had another potential source of news: the English merchants he had worked alongside or befriended while there. These included Elizabeth's financial agent, Thomas Gresham, and Richard Clough, Gresham's factor in Antwerp. Clough, who had access to avvisi, sent news of France, Scotland, the Netherlands, and Italy and even made provision for one of his servants to write to Chaloner when he was unable. ${ }^{35}$ Stephen Becon, a London merchant who traded in Bilboa and who acted as a courier for Chaloner on several occasions, provided further access to merchants' news. ${ }^{36}$ In other cases, the merchants who approached the ambassador for help redressing what they perceived to be wrongs done to them by foreign nationals offered information, perhaps envisioning this as a quid pro quo for Chaloner's efforts on their behalf. ${ }^{37}$ Chaloner's position also gave him contacts with English merchants in various Spanish ports which held the potential to turn into hubs in his information network and even provide him with news of extraEuropean occurrences. ${ }^{38}$ Their utility in this regard was twofold: they provided intelligence that Chaloner could use at Philip's court and news that he could include in his diplomatic reports.

While news was essential to a diplomat's ability to operate abroad, the acquisition and reporting of foreign news was one of his key functions. Even the rumours he encountered at court might be included in his regular missives home. Ambassadors were, however, keen to give some indication of the quality of the information they provided. Sir Edward Stafford, Elizabeth's ambassador in France for much of the 1580 s, for instance, placed marks in the margins of

\footnotetext{
33 See for example $C S P F, 4: 963 ; 5: 155,180,196,200,234$.

34 CSPF, 5: 249, 342, 392, 394, 448, 455, 553, 564, 577, 651, 758, 806, 807, 815, 921, 931, 988, 1054, $1075,1322$.

35 CSPF, 5: 172, 189, 273, 378, 518, 601, 715, 721, 816, 845, 971, 1192; 6: 182, 183, 249, 420, 669, 673, $1000,1127,1189,1208,1296,1331,1395 ; 7: 1435$. This relationship also had a practical component as Gresham and Clough were often involved in transferring funds to Chaloner.

36 John Roche Dasent, ed., Acts of the Privy Council of England, 46 vols. (London, 1890-1964), 7: 122; CSPF, 5: 171, 248, 257, 333, 895, 1311, 1320.

37 CSPF, 4: $960 ; 5: 1456 ; 6: 1543$.

$38 \quad \operatorname{CSPF}, 4: 808,899,960,983 ; 5: 140,147,279 ; 6: 254,944,1465 ; 7: 86,499,630,649$.
} 
some of his letters to indicate which information he had been able to verify. ${ }^{39}$ Chaloner regularly reported on Spanish affairs to Cecil and the Privy Council, making efforts to highlight which information was considered merely rumour and which he believed was more credible. ${ }^{40}$ Although Chaloner predominantly reported to Cecil, Elizabeth, or the Council, he also wrote to individual councillors, most notably Sir John Mason. ${ }^{41}$ Francis Russell, earl of Bedford, Robert Dudley and Nicholas Wotton also received reports and reciprocated. ${ }^{42}$ For Chaloner, as for most Elizabethan ambassadors, it was essential to maintain relationships with individual councillors via individual letters that complemented those sent to Cecil or the Council. These often combined intelligence of foreign affairs with personal business. Chaloner may have sometimes misjudged the balance between information and supplication in his letters to "pryvat consellers", as one friend believed that they were not always sufficiently engaged with political developments, advising the ambassador to "inlarge more graver matters ... and let hyt appeare unto them what a minister you be to preserve ye to augmente $\mathrm{k}$ [ing] P[hilip's] amytye". 43

Many of those who wrote about the role of an ambassador, such as Étienne Dolet, recommended that diplomats should have a man who would collect local information for them. ${ }^{44}$ Chaloner had William Phayre, who provided practical services such as arranging for Chaloner's interviews with the Spanish king and appropriate accommodation during his stays at court. ${ }^{45}$ Phayre also sent Chaloner intelligence from the Spanish court when Chaloner was lodged elsewhere, assuring the ambassador that he wrote "everye daye suche opinions as here are amongst the best sort of embassadoris and such as theye wryte home to ther masters" and so ensured that Chaloner was as apprised of the latest news as his peers. ${ }^{46}$ Phayre was keen to stress that he was not indiscriminately passing on rumours, but was only forwarding news that the other ambassadors believed. Members of Chaloner's household would have been expected to keep their ears to the ground and to inform the ambassador of any

\footnotetext{
39 BL, Additional MS 35841, fo. $48 \mathrm{r}$.

40 See for example $C S P F, 4: 877,1028 ; 5: 52,58,138,171,333,473,1307 ; 6: 553 ; 7: 831$; Dasent, ed., Acts of the Privy Council, 7: 122, 132-3.

$41 \quad \operatorname{CsPF}, 4: 878,959,1018 ; 5: 262,406,557,827,1332 ; 6: 187,365,406,547,1136,1332 ; 7: 463,596$, 833 . 
credible news they heard. Several did not stay for the duration of Chaloner's mission; some of these men corresponded with Chaloner after their departure from Spain. For instance Henry Cobham, who had accompanied Chaloner to the Spanish court, became a correspondent after he left Spain in $1562 .{ }^{47} \mathrm{In}$ doing so, he was effectively continuing his role as a gatherer of information for the use of the ambassador, but this time as part of the ambassador's wider international network.

All Elizabethan ambassadors had one further key potential source of news: members of their host court. It was widely acknowledged that hospitality obliged guests to share information, something that later diplomatic theorists suggested ambassadors exploit. ${ }^{48}$ Chaloner cultivated links with other ambassadors at Philip's court, particularly his French equivalents. It is clear that he often extracted important titbits from his peers. ${ }^{49}$ His ability to do so was, however, hampered by the infrequency with which updates from Elizabeth's court arrived, for the importance of domestic news partly lay in the ability it gave an ambassador to exchange information with his peers. When it came to other diplomats' news "he that will know of theirs, must partly commicat his"; it therefore hurt an ambassador's ability to operate effectively when he was "hable to saye leest, by meanes whereof I have the lesse countenance through conference to demande at them of theire Novelles, seinge I cann so smally requite them withe any of owrs".50 The same was true with courtiers. Chaloner compared news to financial security, explaining to Cecil that "like as a merchaunt keeping his credite may borowe thrise more then he is wourth, So farith it with an Ambassador who through frequent avises from home, seeming to know somewhat, shall often apon credit come by knowledge of $\mathrm{x}$ tymes more then his owne".51 This was an astute point. If Elizabethan diplomats had no news to trade, their standing at court would soon decline.

Through his official duties Chaloner had fairly regular access to Gómez Suárez de Figueroa, count of Feria, one of Philip's councillors and the king's secretary, Francisco de Erasso, who provided official news. ${ }^{52}$ Chaloner had occasional access to the king's physician Andreas Vesalius and met a range of people at court, such as the banker Meliadus Spinola, who were potential

\footnotetext{
$47 \quad C S P F, 5: 884,923,986,1018,1055 ; 6: 743,1071,1211,1524$.

48 Jean Hotman, The Ambassador (London, 1604), sig. G3r-v.

49 See for example $C S P F, 5: 46,88,266,435,514 ; 6: 708,722,735,901,903,1034 ; 7: 93,494$.

$50 \quad$ TNA, SP 70/6, fo.139r, 70/36, fo. 7or [CSPF, 1: 1258; 4: 1018].

$5^{1} \quad$ TNA, SP 70/43, fo. 36r [CSPF, $\left.5: 859\right]$.

$5^{2} \quad$ CSPF, $5: 907 ; 6: 568 ; 7: 466,856$.
} 
sources of information. ${ }^{53} \mathrm{He}$ also appears to have fostered links with English Catholics in Spain, such as Jane Dormer, countess of Feria, and her ladies. ${ }^{54}$ Other English exiles were part of Chaloner's information network, such as Richard Shelley, a knight of St John and former English diplomat, who was initially a supplicant to Chaloner and a person of interest the ambassador felt obliged to watch but later became an associate and correspondent. ${ }^{55}$

Chaloner complained that "this denne or deserte of Spaine is so farre out of the common trade of avises from all partes, as almost all other ambassadors fynde them selves in my case touching newes from abrode". ${ }^{56}$ Avvisi took longer to reach Madrid and were often delayed by the wars in France. Consequently, when newsletters did arrive Chaloner was particularly keen to access them. ${ }^{57}$ Madrid compared poorly to Brussels, an important node in the north European postal network and centre of news, where Chaloner had had frequent access to avvisi, which he had included in his reports. ${ }^{58}$ The large number of avvisi in the Elizabethan state papers attest to the important role they came to play in English diplomacy. ${ }^{59}$ Other Elizabethan ambassadors similarly acquired avvisi for inclusion in their letters home and those stationed in the Netherlands and France were most likely to do so. ${ }^{60}$ Sometimes the embassy secretary copied out or even translated the avvisi, on other occasions printed copies were included in the diplomatic packets. ${ }^{61}$ Forwarding bought avvisi was the most efficient practice as it saved the secretary time and even when the ambassador's budget was tightly stretched, avvisi were a relatively affordable commodity. In operating in this way, English ambassadors were acting comparably to their Imperial counterparts who were also important intermediaries in the spread of newsletters across Europe. ${ }^{62}$

$53 \quad \operatorname{csPF}, 5: 46,93 ; 7: 37$.

54 A.J. Loomie, The Spanish Elizabethans: The English Exiles at the Court of Philip II (London: Burns \& Oates, 1963), pp. 99-100; CSPF, 4: 877, 960, 988, 1029, 1056; 5: 278, 866, 921, 1455; 6: 517, 749, 925, 1213; 7: 526, 676, 748, 749 .

55 BL Harley MS 699o, fo. 7r; CSPF, 5: 859, 884, 1097; 6: 1132; 7: 213, 1122.

56 TNA SP $70 / 37$, fo. $137 \mathrm{~V}$ [CSPF, $5: 88]$.

57 CPSF, 5: 413, 557, $115^{2}$.

58 CSPF, 2: 279, 354, 516, 550, 588, 640, 673, 694. Andrew Pettegree, The Invention of News: How the World Came to Know about Itself (London: Yale University Press, 2014), pp. 18, 37, 54.

59 See for example $C s P F, 4: 118,119,203,228,248,256,300,327,327,372,393,394,465,470,526$, 6o2, 669, 693, 694, 702, 737, 738, 758, 778, 779, 783, 792, 793, 836, 980, 981.

6o See for example $C S P F, 12:$ 199, 396; 13: 535; 14: 157, 494; 16: 179; 17: 93; 18: 20, 122.

$61 \quad \operatorname{CSPF}, 7: 1887,1897$. The majority of newsletters in the State Papers are handwritten.

62 Zsuzsa Barbarics-Hermanik, 'Handwritten Newsletters as Interregional Information Sources in Central and Southeastern Europe', in Dooley, ed., Dissemination of News, 
Chaloner appears to have appreciated the importance of news to ambassadors long before his Elizabethan embassies, for he requested information to pass on to foreign ambassadors while a clerk of the Privy Council in Edward VI's reign. ${ }^{63}$ His experience of diplomatic service led him to make several recommendations about Elizabeth's own news network and what he perceived to be "This only error of ours (I meane want of comely advertysementes)". As Elizabeth's religious settlement severed relations with Rome, Chaloner proposed that a trusted man be posted there as a diplomatic agent who could inform the Privy Council of Roman news. He also suggested that Elizabeth invest three hundred pounds per year buying news from abroad as "No prince canne make accompt what to spende or what to spare if he here not how his Neybours procede". This modest investment, he went on to claim, might save Elizabeth one hundred thousand pounds a year on unnecessary military campaigns. ${ }^{64}$

Chaloner believed that ambassadors alone were unlikely to be able to convey news to the Privy Council regularly enough to keep them apprised of developments abroad and his experience highlights that this was, in fact, the case. Consequently, Elizabeth's Privy Council supplemented their network of diplomats with links to agents in a number of cities. John Mason, for instance, received regular newsletters in the 1560 s from Niccolò Stopio, a professional newsgatherer in Venice with links to the Venetian chancellery. ${ }^{65}$ Stopio wrote with a clear expectation that his letters would be reciprocated, no doubt hoping for English news that he could include in his newsletters to potentates on the continent. ${ }^{66}$ After Mason's death, Stopio wrote to Cecil instead. Stopio's base in an important news hub gave Mason and then Cecil regular access to the latest information and he often tried to indicate what he thought of the quality of the news he was passing on. ${ }^{67}$ Cecil meanwhile, received weekly

pp. 161, 173; idem, "The Coexistence of Manuscript and Print: Handwritten Newsletters in the Second Century of Print, 1540-1640', in The Book Triumphant: Print in Translation in the Sixteenth and Seventeenth Century, ed. Malcolm Walsby and Graeme Kemp (Leiden: Brill, 2011), pp. 363, 365 .

63 Conyers Read, Mr Secretary Cecil and Queen Elizabeth (London:Jonathan Cape, 1955), p. 56.

64 TNA, SP 7o/45, fos. 85v-86r [CSPF, 5: 1097].

65 See $C S P F, 4: 392,464,484,501,545,675,701,913,973,890,927,1027,1049 ; 5: 53,186,227,301$, $405,1442,1468$.

66 CSPF, 4: 701. On Stopio see Mario Infelise, 'From Merchants' Letters to Handwritten Political avvisi: Notes on the Origins of Public Information', in Correspondence and Cultural Exchange in Europe, ed. Francisco Bethencourt and Florike Egmond (Cambridge: Cambridge University Press, 2007), pp. 41-2.

$67 \quad C S P F, 4: 890$. 
newsletters from John Shers in Italy, ${ }^{68}$ who was himself the recipient of numerous newsletters from another newsgatherer, Marsilio della Croce, when he was not based in Venice. ${ }^{69}$ Shers continued to send Cecil newsletters even when in England or northern Europe. ${ }^{70}$ Such links to professional newsgatherers prefigured, and were not superseded by, key privy councillors such as Cecil and Francis Walsingham establishing links with intelligencers and effectively building overseas spy networks. ${ }^{71}$ Contemporaries were keen to distinguish between the honourable gathering of news by ambassadors and their households and the illicit, disruptive activities of intelligencers. ${ }^{72}$ Although Elizabethan ambassadors increasingly had recourse to expend money on "spialls", they were careful not to be seen engaging spies as this would damage their credit and potentially damage relations with the prince to whom they had been sent.

An individual ambassador's network was contingent upon several factors, notably where he was posted, his family, his previous professional connections, and his circle of friends. ${ }^{73}$ Ambassadors benefitted from having highly placed friends and family at home who were well placed to supplement the news being sent by official means with rumours, gossip, and inside information. Contact with the English diaspora was advantageous too, whether that involved links to the mercantile community, scholars studying at foreign universities, religious exiles or a mixture of the three. Where an ambassador was stationed also impacted upon his information network. For most of Elizabeth's

68 CSPF, 4: 202. See for example $C S P F, 3: 349,417,449,496,525,630,694,729,783,799,816$, $822,864,865,877,878,893,894,934,955,1000,1023$.

69 See for example Robert Lemon, ed., Calendar of State Papers Domestic of the Reigns of Edward VI, Mary and Elizabeth, 1547-1580, 7 vols. (London, 1856-71), I Eliz XXIV 46, 49, 52; CSPF, 7: 1128, 1840, 1841.

70 See for example $C S P F, 4: 225,287,365,433,499,525$.

71 On Elizabethan spy networks see Alan Haynes, The Elizabethan Secret Services (Stroud: The History Press, 200o); Robyn Adams, 'A Most Secret Service: William Herle and the Circulation of Intelligence', in Diplomacy and Early Modern Culture, ed. Robyn Adams and Rosanna Cox (Basingstoke: Palgrave Macmillan, 2011), pp. 63-81; Stephen Alford, 'Some Elizabethan Spies in the Office of Francis Walsingham', in ibid., pp. 46-62. On the development of European spy networks see Daniel Szechi, ed., The Dangerous Trade: Spies, Spymasters and the Making of Europe (Dundee: Edinburgh University Press, 2010).

72 Hotman, Ambassadour, sig. I4r-v; Thomas Palmer, An essay of the meanes how to make our travailes, into forraine countries, the more profitable and honourable (London, 1606), sigs. B2r-B3v.

73 On the importance of personal networks to early modern ambassadors see Christian Windler and Hillard von Thiessen, eds., Akteure der Aussenbeziehungen: Netzwerke und Interkulturalität im historischen Wandel (Cologne: Böhlau, 2010). 
reign, a posting to France necessitated cooperation with diplomats in the Netherlands, Spain, and Scotland, while for a mission to Scotland contact with English ambassadors posted in countries other than France was less crucial. Consequently, while all English diplomatic networks shared some common features they also varied from ambassador to ambassador, even among those posted to the same court. These differences were magnified by the fact that diplomats posted in Brussels or at the French court had access to more active centralised print industries as well as thriving local presses, while those in Scandinavia or Scotland could not utilise the press in the same way. Moreover, as hubs in the European postal network Brussels and Paris were centres of the nascent news industry. ${ }^{74}$

An increasingly important source of news was the foreign press. English ambassadors kept a keen eye on the published works circulating in the countries to which they were posted, not least those works that redounded to the honour or dishonour of their own monarchs. Hence Nicholas Throckmorton was keen to suppress an edition of Henry viı's Assertio septem sacramentorum printed at Lyon in 1561 which had defamatory material about Elizabeth I's mother, Anne Boleyn, added in a preface written by Gabriel de Sacconaye. ${ }^{75}$ Equally, when tracts were published that derided the English church, Elizabeth's diplomats were keen to argue that they should be suppressed and, if that were not possible, that the English should be allowed to publish their answers to such tracts without hindrance. ${ }^{76}$ Many such books were lengthy polemical and theological works. ${ }^{77}$ But as Elizabeth's reign progressed, her diplomats found that they needed to be increasingly aware of libels and other cheap printed or manuscript material that denigrated the queen, her councillors or her church. Stafford, for instance, was faced with satirical defamatory images of Elizabeth while in France in the 1580 os $^{78}$ Other diplomats had to deal with printed libels and placards aimed at the queen and her military commanders. These were

74 On the comparative size of the printed output of European countries and their book markets see Andrew Pettegree, The Book in the Renaissance (London: Yale University Press, 2010), pp. 249-69, 357 .

75 CSPF, 4: 496, 516, 591. Regis Anglice Henrici hujus nominis octavi assertio septem Sacramentorum adversus Martinum Lutherum (Lyon, 1561). The preface was transcribed and sent as a separate document: $\operatorname{CSPF}, 4: 498$.

76 See, for example, Thomas Smith's efforts to get Walter Haddon's answer to Hieronymus Orosius printed: $C S P F, 6: 1463,1517 ; 7: 99,229,388$, or the efforts to suppress Patrick Adamson's Serenissimi ac Nobilissimi Scotiae, Angliae, Hyberniñe Principis, Henrici Stuardi invictissimi herois, ac Mariae Reginae amplissimae filii Genethliacum (Paris, 1566), USTC 158178; csPF, 8: 798 .

77 See for example $C S P F, 4: 833 ; 15: 670$.

78 CSPF, 18: 246, 486. 
routinely sent to the secretary or council, often with whatever information the ambassador had been able to gather about their circulation. ${ }^{79}$ Diplomats could, in turn, expect to be updated on the Council's efforts against seditious and libellous foreign print. ${ }^{80}$ This meant that the diplomats and the Privy Council often coordinated their efforts against problematic print.

Ambassadors considered much of what was being printed abroad news. Information about the sorts of publications that were available, the contents of particular types of works, and the dissemination of specific items were all deemed sufficiently important to be included in diplomatic reports. Much of the effort of English diplomats to monitor foreign presses, however, focussed on official pronouncements, statements issued by those in opposition to the government, and cheap print and pamphlets about religious and political controversies. The range of works as ambassador might consider newsworthy is illustrated by a packet Thomas Smith relayed to Cecil in October 1563. This included the French ambassador's protestation at the Council of Trent; a book declaring Charles IX's majority, with the remonstrance and accord of the Parlement of Paris on the subject; the 'supplication' of the Guise; a French book on Newhaven; and the Admiral's further answer about the death of the Duke of Guise. ${ }^{81}$ So Smith believed that official pronouncements, religious polemics, and news pamphlets would all be of interest to the English government. He was, however, careful to give some sense of the priority Cecil should accord them, indicating that only one was "worth the reading". ${ }^{82}$ For a diplomat, whether a particular publication counted as news depended on the context, usually fitting into one of four categories: items that related to any developments (whether political, religious, economic or social) in the country in which he was stationed that might improve the English privy council's understand of how to conduct their diplomacy with it; items that impacted upon Englishmen who travelled to the country; items that helped the Privy Council understand popular sentiment in the country; and items that might be useful for English domestic purposes.

\footnotetext{
79 See for example $c S P F, 23: 485$; BL, Cotton Ms Galba D X, fo. 49r.

80 BL, Cotton MS Galba D viII fo. 218r; BL, Cotton MS Galba D IV, fo. $175 \mathrm{v}$.

$81 \quad C S P F, 6: 1292$. The pamphlets were possibly (in order) La harengue des ambassadeurs $d u$ roy de France Charles IX prononcée en Latin au concile general de Trente (Paris, 1563), USTC 6o170; Jean du Tillet, L'entiere majorité du tres-chrestien roy Charles IX (Paris, 1563), UstC 89551; Response aux presidens et conseilliers de sa cour de Parlement de Paris sur la remonstrance faicte à sadicte majesté, concernant la declaration de sa majorité (Lyon, 1563), USTC 3859; TNA, SP 70/53, fo. 24r-v (a manuscript); Discours au vray de la reuction du havre de grace en l'obeissance du Roy (Paris, 1563), ustc 10259; Gaspard de Coligny, Response a l'interrogatoire qu'on dit avoir este faite a un nommé Jean de Poltrot (several editions in 1563).

TNA, SP 70/64, fo. $40 \mathrm{OV}$ [CSPF, 6: 1292].
} 
Official proclamations, edicts, and ordinances were prominent among the types of news Elizabethan diplomats gathered and relayed. Indeed, Cecil explicitly asked ambassadors to send him official pronouncements and most English ambassadors believed that it was part of their job to procure this information. ${ }^{83}$ Smith, for instance directly charged members of his household with finding new printed pronouncements. ${ }^{84}$ Perhaps unsurprisingly, his secretary, Henry Middlemore, also forwarded edicts to Cecil. ${ }^{85}$ At times ambassadors were eager to convey official news before a royal edict had been printed. For instance Smith sent a transcript of the declaration of Charles IX's majority from the Register of Rouen as there were not yet any printed copies. ${ }^{86}$ But they were careful to explain the exact status of the items included in their reports. Hence in January 1562, Throckmorton cautioned that the edict he was sending should not be taken as an authorised ordinance, as the Paris Parlement had rejected it. ${ }^{87}$ While such material was predominantly sent to the principal secretary or the Queen, ambassadors often sent duplicate items to other members of Elizabeth's Privy Council. ${ }^{88}$ Ambassadors also often indicated who they believed should be given copies of the texts they procured. Throckmorton, for one, was not shy of instructing Cecil that imprints needed to be brought directly to Elizabeth's attention. ${ }^{89}$

The papers of representative assemblies and councils were of equal interest to those issued solely by royal authority. Ambassadors stationed in Scotland sent copies of bills from the Scottish Parliament in their despatches while those in France often included the edicts of the Paris Parlement and the laws passed by the Estates General..$^{90}$ Throckmorton was so eager to keep his queen informed of developments that he acquired scribal publications issued by groups trying to influence the Paris Parlement. ${ }^{91}$ Meanwhile Chaloner passed on copies of propositions made by Philip II to the lords of Aragon in October

83 Scrinia Ceciliana mysteries of state \& government: in letters of the late famous Lord Burghley, and other grand ministers of state, in the reigns of Queen Elizabeth, and King James, being a further additional supplement of the Cabala (London, 1663), 127; CSPF, 5: 1013; 6: 223, 424, 561, 781; 17: 167, 286.

$84 \quad C S P F, 5: 1274$.

85 CSPF, 6: 617 .

$86 C S P F, 6: 1463$.

$87 \quad C S P F, 4: 849$.

$88 C S P F, 6: 561$; TNA, SP $70 / 66$, fo. $35 \mathrm{~V}$ [CSPF, 6: 1463].

89 CSPF, 5: 67.

$90 \quad C S P F, 3: 434 . ; 4: 592 ; 17: 167$.

$91 \quad \operatorname{CSPF}, 4: 374$. 
1563, allowing Elizabeth and her council to see the process of political negotiation the Spanish king undertook. ${ }^{92}$

Elizabethan ambassadors included a wide range of printed proclamations and ordinances in their dispatches. Those stationed in France, which had a thriving print industry, sent back larger numbers of official imprints than those based in areas with a less developed print culture. In the second half of the sixteenth century, a large proportion of French royal edicts were printed in Paris and by the provincial presses. ${ }^{93}$ The edicts sent from France included pronouncements that helped to clarify matters of importance when conveying money to ambassadors or that might be of concern to the English mercantile community such as proclamations that regulated French coinage. ${ }^{94}$ On occasion, they also included public health announcements such as the proclamation setting out how Lyon was to be managed during an outbreak of plague in the city in $1564 .{ }^{95}$ Ordinances of foreign royal households were also considered important, no doubt because they had implications for which courtiers English ambassadors needed to cultivate and because they might contain changes that would impact on court ceremonial. ${ }^{96}$ There is some evidence that newsgatherers also believed that monitoring official print was within their purview. Among the printed pamphlets in the State Papers at The National Archives at Kew is a copy of the printed regulations of the Council of Ten for the government of Venice, which was probably included in the packets of one of William Cecil's regular informants. ${ }^{97}$

Official print that dealt with battles and diplomacy was understandably of considerable interest to English politicians. Many of these concerned military matters, ranging from ordinances about the refortification of border towns to proclamations concerning the musters. ${ }^{98}$ Such information was vital to the English government's own strategic reasoning about any military intervention and the preparedness of any forces they might meet should they do so.

\footnotetext{
$92 \quad \operatorname{CSPF}, 6: 1337$.

93 Andrew Pettegree, Growth of a Provincial Press in Sixteenth-Century Europe (Reading: University of Reading, 2006), pp. 25-6.

$94 \quad C S P F, 8: 591$. De par le Roy et les Generaulx des ses monnoyes (Paris, 1566).

95 CSPF, 7: 544. L'Ordonnance de messieurs les Commissaires depputez par le Roy, pour le faict de la police et santé de la ville de Lyon (Lyon, 1564), USTC 24403.

96 R. Cecil et al., eds., Calendar of the Manuscripts of the Most Hon. The Marquis of Salisbury, 24 vols. (London 1883-1976), 3: 123.

97 CSPF, 13: 975. Parte presa nell'Eccellentiss-conseglio di $X$ et giunta (Venice, 1567), USTC 823718 .

$98 \quad C S P F, 8: 891,797$. On the broader interest in military news in Elizabethan England see David Randall, Credibility in Elizabethan and Early Stuart Military News (London: Pickering \& Chatto, 2008).
} 
Elizabeth's ambassadors in France forwarded publications detailing the French crown's military victories, such as that at the battle of Dreux in December $1562 .{ }^{99}$ Even more crucial were texts that dealt with military campaigns in which the English were involved. Hence Smith was eager to send proclamations about the French attempts to remove the Huguenots and the English from Le Havre in $1563 .{ }^{100}$ Diplomatic events such as declarations of peace or the meeting of the French and Spanish courts at Bayonne in 1565 were also considered newsworthy. ${ }^{101}$

Official pronouncements concerning heresy and prohibited books were of considerable interest because they indicated the religious tenor of a country. It was important for English merchants and diplomats to know the latest religious regulations in those countries which adhered to a different confession to England if they were to safeguard against accusations of heresy. When Chaloner included the reissue of a 1556 Dutch ordinance against heresy and prohibited books in a letter to the Queen in November 1559, he no doubt did so because it was to have almost immediate effect and because it affirmed the powers of the Spanish Inquisition in the Netherlands. ${ }^{102}$ Elizabethan ambassadors in France similarly passed on the various royal edicts that outlined the extent of toleration afforded to the Huguenots. ${ }^{103}$ Accuracy and credibility were key concerns motivating Elizabethan diplomats' mediation of religious news. When the scribally published texts Throckmorton had procured were different from their printed versions, he was eager to send the latest version. ${ }^{104}$

Elizabeth's ambassadors reported on the topical news pamphlets available in the cities where they were posted and included such pamphlets in their despatches. Even those posted in countries with a comparatively nascent print industry purchased topical print for the Privy Council. Randolph, for instance, sent Cecil and the Privy Council a range of works from Scotland. ${ }^{105}$ Often ambassadors did not specify the exact nature of the print they forwarded the

99 CSPF, 5: 1282. Brief Discours de ce qui est advenu en la bataille donne pres la ville de Dreux ([Orléans], 1562), ustc 27036 .

$100 \quad$ CsPF, 6: 720, 753. Lettres patentes du roy par lesquelles est permis de porter viures au camp \& armée (Paris, 1563 ), USTC 56335.

$101 C S P F, 7: 309,310,1277$. Brief Discours de la joyeuse entreveve de treshaute \& tres excellente Elizabeth de France Royne Catholique d'Espaigne, es environs de la ville de Bayonne (Paris, 1565), USTC 16236.

102 TNA, SP 70/8, fo. $118 \mathrm{v}[\operatorname{CSPF}, 2: 220]$.

103 See for example $C S P F, 4: 357 ; 6: 473 ; 7: 516 ; 8: 818,1878$.

104 CSPF, 4: 930.

105 CSPF, 6: 558; W.K. Boyd, ed., A Calendar of Papers Relating to Scotland and Mary, Queen of Scots, 1547-1604 (Edinburgh, 1903), 2: 343; 4: 237. 
Cecil and the Council, merely indicating that they were recent imprints. ${ }^{106}$ Moreover, they often included such material in the same packets that contained avvisi and edicts, suggesting that they did now draw a clear distinction between newsletters and other media that contained information with contemporary resonance. ${ }^{107}$ The decision to send topical print was motivated by the need to gather as much information as possible about events and how they were perceived, not the intrinsic quality of the work, as Smith's sending of a book on the troubles in Languedoc, Montpellier, and Nîmes to Cecil demonstrates. Smith believed that "if yt had not a fewe faultes I would saye yt were worth the reading. Yt lacketh but wit, good order, and truth, nor yt ys not in deede verie good french". 108 Yet Smith sent it anyway. Some ambassadors even forwarded books that they had not read, but believed to have some currency. ${ }^{109}$

Printed works that offered insights into political relationships and the status of individual members of the elite were also considered newsworthy by Elizabeth's ambassadors. Hence in 1559 Chaloner sent Cecil a pamphlet which detailed the current Knights and the history of the Burgundian chivalric Order of the Golden Fleece. ${ }^{110}$ This was no doubt motivated, in part, by Chaloner's knowledge that Cecil was interested in such matters. But the practical information it gave about the membership of the Order was also pertinent. Throckmorton too, believed that new tracts detailing political connections should be brought to the attention of Elizabeth's councillors, sending a book detailing the heraldry and genealogy of the French elite in $1561 .{ }^{111}$ Genealogical works could have broader political resonance, such as the work Henry Cobham included in a packet from France in March 1582, which also detailed Don Antonio's claim to the Portuguese crown. ${ }^{112}$ Unofficial pamphlets which conveyed military news, understandably, featured prominently among the works brought to the Council's attention. Indicative of the ambitions of ambassadors was a list of books that Smith had instructed his courier to procure for Cecil if they were available: a discourse of the recent wars in Hungary, the history of the wars in Malta, and 'La Guerre Cardinale', a pamphlet about the Cardinal of Lorraine's campaigns. ${ }^{13}$ Tracts about the French religious wars could be found

\footnotetext{
106 See for example $C S P F, 4: 1044 ; 5: 735 ; 6: 169 ; 18: 20 ; 122$.

107 See for example $C S P F, 1: 1392 ; 2: 297,550$.

108 TNA, SP 70/74, fo. 186r-v [CSPF, 7: 755].

109 Boyd, ed., Calendar of Papers Relating to Scotland, 3: 242; CSPF, 19: 930.

$110 \quad C S P F, 2: 225$.

111 This was probably Alliances genealogiques des rois et princes de Gaule (Lyon, 1561).

112 CSPF, 15: 616.

113 CSPF, 7:1512.
} 
in the packets of every Elizabethan ambassador to France. ${ }^{114}$ In addition, ambassadors sent cartographic news-maps of sieges, battles and towns where military action was occurring — some of which were printed and others hand drawn. ${ }^{115}$

Religious controversies and pamphlets detailing the progress of Protestants on the continent featured heavily among the 'news' pamphlets Elizabeth's ambassadors procured. The volatile religious situation in France was of particular interest to English politicians. Throckmorton, for instance, sent Cecil and the Council a range of Huguenot literature including petitions and placards, polemical tracts, and proclamations by the king of Navarre. ${ }^{116} \mathrm{He}$ also sent several anti-Guise tracts, such as the pamphlets published condemning the Guise for the massacre at Vassy. ${ }^{117}$ As the Guise were a favourite target of Huguenot controversialists, anti-Guise works continued to feature in Elizabethan diplomatic packets. ${ }^{118}$ For Throckmorton, the value of such pamphlets was the reassurance they gave that the Guise were too preoccupied with their own troubles in France to represent a real threat to Elizabeth. ${ }^{119}$ Catholic controversial literature, including speeches and pro-Guise tracts, were also considered noteworthy. ${ }^{120}$

Elizabethan ambassadors also sent home short pamphlets of a more sensationalist nature. Several conveyed news of unusual events that contemporaries might be inclined to interpret as signs of god's providence. Hence in November 1562 Chaloner enclosed a copy of an advice to Philip II in his despatch to Cecil. This told of a fire in the Azores that had devastated one of the islands. Chaloner's report linked this to a recent earthquake in Madrid that had scared the Franciscans out of their monastery, and a recent monstrous birth. ${ }^{121}$ Similarly, in June 1561 Nicholas Throckmorton included a cheap French 'paper'

114 See for example $C S P F, 14: 447$; 18: 205; Hatfield House, Cecil Papers 162/122.

$115 C S P F, 2: 550,5: 841,842 ; 6: 131,223,225,239$, 1009; 8: 801, 1369. On the importance placed on cartographic news see Peter Barber, "Procure as many as you can and send them over": Cartographic Espionage and Cartographic Gifts in International Relations, 1460-176o', in Diplomacy and Early Modern Culture, ed. Adams and Cox, pp. 13-29.

116 CSPF, 4: 237, 395; 5: 100, 174, 596.

117 See for example $C S P F, 2: 1082 ; 3: 34,67,234 ; 4: 1013$.

118 Luc Racaut, Hatred in Print: Catholic Propaganda and Protestant Identity During the French Wars of Religion (Aldershot: Ashgate, 2002), pp. 72-6.

119 CSPF, 2:116, 317.

$120 \quad C S P F, 3: 516,616 ; 7: 1108,1512$.

121 TNA, SP 70/45, fos. 82v-3r [CSPF, 5: 1097]. The advice was probably Relacion muy verdadera trayda por Diego Die y Juan Rodriguez y Pedro Morzillo viniendo de sancto Domingo, en la qual se trata del gran fuego y encendio que a avido en una isla llamada el Pico (Seville, 1562), USTC 346404 . 
about recent unusual events in Provence in one of his despatches to Cecil. ${ }^{122}$ For Throckmorton, the significance of the work lay not in its sensationalism, but in its potential to affect interpretations of English events. He viewed the strange sights in the context of the destruction of the steeple and roof of St Paul's in London on Corpus Christi eve. In England, this calamity was interpreted in providential terms either as proof that God disfavoured Elizabeth's religious settlement, or as evidence that Englishmen and women were not embracing the settlement and its doctrines with sufficient zeal. ${ }^{123}$ At the French court and in the paratextual material of one of the French pamphlets on the event it was seen as a providential punishment for Elizabeth's rejection of the papacy and had provoked comparisons between England and Sodom..$^{124}$ But equally strange occurrences in France demonstrated that God was not singling out England.

In many European countries, songs were a means by which news was orally transmitted, while ballads were often reworked to bring them in line with current events. No wonder, then, that some Elizabethan diplomats considered ballads news. ${ }^{125}$ Just as English ambassadors reported libellous pamphlets and satires on English political figures, they appreciated that such defamatory material aimed at foreign politicians was also newsworthy. Pasquils conferred information about the reputation of foreign potentates that might prove useful and to demonstrate the state of popular opinion. ${ }^{126}$ Pasquils had a further advantage: they could become a coded way of referring to actual political developments. Hence in December ${ }^{1563}$ Chaloner referred Elizabeth to an Italian pasquinade about Don Luis de Avila that he had included in an earlier missive, suggesting that she infer from this what was occurring in secret. ${ }^{127}$ This concern with popular opinion in other polities explains why some of Elizabeth's ambassadors also believed that prophecies were worth forwarding to the Queen's council. ${ }^{128}$

The Elizabethan regime was not only interested in foreign print for its value as news. It was also keen to know what political and religious print was being produced in case it was in its interests to respond. For instance when

\footnotetext{
122 TNA, SP 70/27, fo. 61v [CSPF, 4: 267].

123 Alexandra Walsham, Providence in Early Modern England (Oxford, 1999), pp. 232-4.

124 Recit veritable du grand temple et clocher de la cité de Londres, en Angleterre, nommé saint Paul, ruiné et destruit par la foudre du tonnerre (Lyon, 1561), USTC 37109, suggested that readers should remember Sodom and Gomora when reading about the events in London. 
Throckmorton sent Cecil the protestation of Michel de Sèvre, the French ambassador in England, which had been recently printed at Tours, he recommended that Elizabeth's answer should be printed in Latin and French and published in a composite volume with the ambassador's protestation. But, he suggested, the material should be rearranged so that the infractions were placed most prominently in the volume and a preface added to frame the material. Throckmorton paid close attention to the material he was sent, giving Cecil his opinion of Cecil's translations. ${ }^{129}$ His advice appears to have been followed. ${ }^{130}$

Foreign news was also assessed for its potential to shape opinion at home. Lisa Parmelee has demonstrated how Stafford was "the single most demonstrably active supplier of French political propaganda to his government in the 1580s". From his position in Paris, Stafford provided the English government with a steady stream of French imprints, many of which the government found it beneficial to publish in English translation. Parmelee dates the English interest in French print to the wake of the St Bartholomew's Day massacre, meaning that these translations found a ready audience. Pointing to roughly 130 works on the French wars and French pamphlets in English translation that were printed between 1585 and 1595 , Parmelee rightly suggests that their appeal was that they were predominantly anti-Guise, anti-Spanish, and anti-Jesuit. ${ }^{131}$

An examination of the activities of Elizabethan ambassadors to France reveals that they all performed this very same duty: they all regularly sent back tracts containing news of political and religious events and they often highlighted the political or religious utility that the publication of such works in English might have to the English government. English renderings of many of these works were then printed by presses associated with links to privy councillors. Throckmorton enclosed dozens of topical French imprints in his reports, largely ones that were concerned with the tumultuous religious and political situation in France, several of which were subsequently printed in English translation. Throckmorton played an important role in the decision to translate and publish several of the tracts he procured. In the autumn of ${ }_{1561}$

$129 \operatorname{csPF}, 3: 116$.

130 Responce a la protestation faicte par l'ambassadeur du roy tres chrestien de la part du roy son maistre à la royne d'Angleterre (London, 1560 ), USTC 76587. This was in response to de Sèvre's Protestation faicte de la part du Roy Treschrestien: par son ambassadeur resident pres la Royne d'Angletere a sa Majesté, \& aux seigneurs de son Conseil. xx. April (London, 1560), Ustc 21645, which was also printed in Orleans, Lyon, and Tours.

131 Lisa Parmelee, 'Printers, Patrons, Readers and Spies: Importation of French Propaganda into Elizabethan England', Sixteenth Century Journal, 25 (1994), pp. 853-72, at 857, 863. 
Throckmorton explicitly recommended the translation and publication of several printed works arising from the discussions at the Colloquy of Poissy. Throckmorton believed that it would be beneficial to publish a speech delivered by Theodore Beza, a copy of which he included in his despatch of 20 September. ${ }^{132}$ Within a week, Throckmorton was assured that the translation was being undertaken by John Mason, a former English ambassador to France, "who wold needes do it him self". Throckmorton had recommended its publication not only in England, but also in Scotland, something which was seemingly achieved. ${ }^{133}$ In November, Throckmorton urged the publication in England of a second oration by Beza, this time his answer to the Cardinal of Lorraine's speech, in a composite volume with both Beza's earlier speech and the Cardinal's "and some of them so pryntyd to be sent into Scotland". ${ }^{134}$ Not insignificantly, given Throckmorton's insistence that Beza's orations should be sent to Scotland, the printer of the Protestant faction in Edinburgh, Robert Lekprevik, printed both Beza's oration of 26 September, and a compilation tract of Beza's first oration and declaration. ${ }^{135}$ In his orations, Beza explained his position on the Eucharist and sought to come to an agreement with the Catholics without compromising on doctrine. Such books were useful in demonstrating the potential for religious compromise. Some members of the English embassy in France turned to the translation of contemporary religiopolitical texts during their service. For instance Jerome Bowes translated Innocent Gentillet's An apology or defence for the Christians in France which are of the evangelicall or reformed religion (1579); it was printed by John Day who had strong links to Cecil. ${ }^{136}$

English ambassadors were instrumental in the wider dissemination of topical pamphlets and political tracts. They frequently circulated works at the

\footnotetext{
$132 \quad C S P F, 4: 518$.

133 TNA, SP 70/30, fo. 109v [CSPF, 4: 540]; CSPF, 4: 518. An oration made by Master Theodore de Beze, minister of the word of God, accompanyed with. xi. other ministers and. xx. deputies of the refourmed churches of the realme of Fraunce, in the presence of the king (London, 1562), USTC 505939. Ane oration made by Master Theodore de Beze, minister of the word of God, accompanyed with. xi. other ministers and. xx. deputies of the refourmed churches of the realme of Fraunce, in the presence of the king (Edinburgh, 1562).

134 TNA, SP 70/32, fo. $58 \mathrm{v}$ [CSPF, 4: 684]. Throckmorton had sent the cardinal's oration in an earlier despatch: $C S P F, 4: 624$.

135 Ane answer made the fourth day of Septembre (Edinburgh 1562), USTC 505950; Ane oration made by Master Theodore de Beze (Edinburgh, 1561), ustc 505834.

${ }_{13} 6$ On Day's relationship with Cecil see Elizabeth Evenden, Patents, Pictures and Patronage: John Day and the Tudor Book Trade (Aldershot: Ashgate, 2008).
} 
courts to which they were posted, giving copies to courtiers and potentates. ${ }^{137}$ Moreover, ambassadors were instrumental in the publication of such works overseas. For instance, while serving as Elizabeth's ambassador in France Henry Cobham oversaw the translation into French or Latin of several works and their publication. Among them was a Scottish complaint against Esme Stewart. ${ }^{138}$ English diplomats were also instrumental in encouraging other potentates to spread English propaganda produced to resemble 'news' pamphlets and encouraging foreign rulers to print translations of such works. For instance in September 1585 after Thomas Bodley presented the king of Denmark with a pamphlet about the Parry plot against Elizabeth, the king commissioned the publication of a German translation of the work. ${ }^{139}$ On some occasions, the English government did not want to be directly associated with such texts. So in the case of the pamphlet against Stewart, Cobham distributed the translation to contacts in Paris, Venice, Geneva, and Germany "as pamphlets sent to me out of Flanders". ${ }^{140}$ Other ambassadors were equally involved in the surreptitious translation and dissemination of texts that the English government considered useful but from which they publicly wished to retain a degree of distance. In some cases, however, the primary reason for secrecy was a concern for the diplomat's safety. In January 1584, for instance, the diplomatic agent Horatio Pallavicino facilitated an Italian version of a tract that he then helped to disseminate in Italy. But Edward Stafford, who reported to the Privy Council on Pallavicino's progress, stressed that "it must not be known who is the doer" or Pallavicino's life would be in danger. ${ }^{141}$

Several recent studies have explored various aspects of the intelligence gathering of the Elizabethan state. ${ }^{142}$ These have tended to focus on espionage and intelligencers. In other words, they have privileged what contemporaries would have considered dishonourable means of information gathering. While Elizabethan ambassadors increasingly turned to illicit intelligence to supplement their legitimately acquired news in the light of confessional wars, the vast majority of the information they gathered was acquired through open means and formed a core diplomatic activity. At the same time, news provided ambassadors with political currency. They traded it with other diplomats and

137 See for example Calendar of Papers Relating to Scotland, 2: 3; CSPF, 7: 1030; 9: 2196; 10: 27, 79 .

$138 \quad C S P F, 14: 424$.

139 CSPF, 20: 14. Bericht von der Verrätterei Willem Parrys (Copenhagen, 1585), USTC 302803.

$140 \quad C S P F, 14: 424$.

141 CSPF, 18: 393 .

142 See Stephen Alford, The Watchers: A Secret History of the Reign of Elizabeth I (London: Allen Lane, 2012); and n. 71 above. 
foreign courtiers for political credit. Possessing more recent and more reliable information than other politicians gave them a strategic advantage. Ambassadors were therefore key intermediaries in the transmission of news across Europe. Their letters, while by no means pure newsletters, predominantly recounted recent developments. The other texts that often accompanied diplomatic letters included news pamphlets, avvisi and other publications that were considered news. There is a tendency to see diplomats who sent books home as cultural agents engaged in brokerage and patronage, and to some extent this was so. ${ }^{143}$ But we should not forget that forwarding books home was simply part of a diplomat's job. With their privileged access to foreign imprints, they played a fundamental role in the transnational circulation of topical and official print. Moreover, they offered advice on which material should be further disseminated, in what form and to whom. As such, they helped to shape the news, broadly defined, not only in England, but also on the continent.

143 See for example Marika Keblusek and Badeloch Vera Noldus, eds., Double Agents: Cultural and Political Brokerage in Early Modern Europe (Leiden: Brill, 2011). 